\title{
Hollis Cline: Leapfrogging over gaps in autism research
}

\author{
BY LAURA DATTARO
}

1 FEBRUARY 2022

\section{Listen to this story:}

https://www.spectrumnews.org/wp-

content/uploads/2022/02/audio-7ecf8765-2c20-4be6-bccf-339dbd158c28-encodings.mp3

Early in her first postdoctoral position, Hollis Cline first showed her hallmark flair for creative problem-solving.

Cline, who goes by Holly, and her adviser, neuroscientist Martha Constantine-Paton, wanted to study the brain's 'topographical maps' - internal representations of sensory input from the external world. These maps are thought to shape a person's ability to process sensory information - filtering that can go awry in autism and other neurodevelopmental conditions.

No one knew just how these maps formed or what could potentially disrupt them. Cline and Constantine-Paton, who was then at Yale University and is now emerita professor of brain and cognitive sciences at the Massachusetts Institute of Technology, weren't sure how to find out.

But as a first step, the pair decided to take the plunge with an unusual animal model: the frog specifically, a spotted greenish-brown species called Rana pipiens, or the northern leopard frog. The amphibians spend two to three months as tadpoles, a span during which their brains change rapidly and visibly - unlike in mammals, which undergo similar stages of development inside of the mother's body. These traits made it possible for Cline and Constantine-Paton to introduce changes and repeatedly watch their effects in real time.

"That's an extended period when you can actually have access to the developing brain," Cline says.

The unorthodox approach paid off. Cline, 66, now professor of neuroscience at the Scripps 


\section{Spectrum | Autism Research News}

https://www.spectrumnews.org

Research Institute in La Jolla, California, worked out that a receptor for the neurotransmitter glutamate, which had been shown to be important for learning and memory, also mediated how visual experiences influence the developing topographical map. She later created a novel live imaging technique to visualize frog neurons' development over time and, sticking with frogs over the ensuing decades, went on to make fundamental discoveries about how sensory experiences shape brain development and sensory processing.

Such innovation and persistence characterize Cline's prolific career — and have made her an especially collaborative scientist, colleagues say. "One of the great things about Holly has always been that she's been able to work and find solutions to problems others have made into obstacles," says Scott Fraser, professor of biology at the University of Southern California in Los Angeles.

As a reward for her efforts, Cline served as president of the Society for Neuroscience from 2015 to 2016; has published more than 200 papers, which have been cited more than 17,000 times, according to Google Scholar; and has been recognized with several mentorship awards. And she continues to extend her scientific reach and innovate, including a recent turn to stem-cell models in search of answers about Rett syndrome.

"There's no limit," says Linda Van Aelst, professor of cancer research at Cold Spring Harbor Laboratory in New York. "She goes for it, if that will answer a question."

Cline's love for the lab started young. As a child, she was captivated by her mother's work as a lab technician, which she started as soon as Cline, the youngest of three, entered school. Cline so wanted to be in the lab that she regularly faked being sick to miss school and tag along. (Her mother, who earned a doctorate in biochemistry in 1965, let her get away with the ruse.)

Cline studied biology at Bryn Mawr College in Pennsylvania and made plans to follow in her mother's footsteps. But in 1977, during her final year, she took a neurobiology course and switched gears. "I was totally enamored with it," Cline says.

So enamored, in fact, that she set aside her graduate school applications and instead took a job as a research technician in endocrinologist Martin Sonenberg's lab at Memorial Sloan Kettering Cancer Center in New York City. She often walked across the street to attend neuroscience seminars at Rockefeller University. And in 1979, she was ready for graduate school — this time in neuroscience, at the University of California, Berkeley, where another chance encounter once again redirected her career.

Cline, who was studying the role of cell lineage in brain development, had to write a paper outside of her direct area of interest to fulfill a school requirement. She focused on the development of the 


\section{Spectrum | Autism Research News}

https://www.spectrumnews.org

visual system and happened upon a question that would motivate her entire career: How does sensory experience help shape the brain's development? After reading Constantine-Paton's 1984 paper on the visual system's development in frogs, Cline decided to return to the East Coast in 1985 to study with her.

Initially they decided to try to unpack how tinkering with the glutamate receptor alters visual system development in frogs, which other teams had demonstrated in goldfish and cats. They found that when they blocked the same receptor in optical cells in the tadpoles' brains, visual signals no longer shaped the map. What's more, the axons of signal-transmitting cells called retinal ganglion cells spread across a wider area and produced a more "scattered" topographical map.

Visual input to the eye, Cline and Constantine-Paton proposed, activates glutamate receptors on certain optical cells, prompting them to form, test and re-form the map's connections. However compelling, though, the model was based on still images of tadpole brains at various time points. Without a method to watch the process unfold in real time, Cline says she felt she would have to abandon her research. "That was a pretty dramatic thought."

The solution came while flipping through the August 1990 issue of the journal Neuron, which featured a study describing a method of dyeing a frog's neurons and recording how they grow and form connections. Cline ran to her phone and called Fraser, the study's lead investigator, who offered to teach Cline his techniques. Cline also switched to a genus of frogs called Xenopus, albino specimens of which are transparent.

"I just remember reading that paper and saying, 'Oh my God, this is amazing," Cline says. "That really opened up a brand-new world, actually, and I started to do everything in live imaging."

After a second postdoctoral fellowship in Richard Tsien's lab at Stanford University in California, Cline set up her first lab at the University of lowa in 1990 and then moved to Cold Spring Harbor Laboratory in 1994. There she created a technique to introduce light-emitting molecules into individual frog cells. "Holly really pioneered this area of in-vivo imaging in the frog," says Elly Nedivi, professor of brain and cognitive sciences at the Massachusetts Institute of Technology.

When Cold Spring Harbor Laboratory began hosting a series of meetings on fragile X syndrome in the 1990s, Cline started to see how her work might support studies of neurodevelopmental conditions. Among the attendees was Michael Tranfaglia, a doctor whose son had recently been diagnosed with fragile $\mathrm{X}$, a condition often accompanied by autism.

Tranfaglia was on a mission to persuade developmental neuroscientists to study the syndrome. "One name kept coming up over and over again, and that was Holly Cline," he says. He convinced Cline to devote some of her time to investigating how mutations in the FMR1 gene, which cause fragile $X$ syndrome, affect brain development. 


\section{Spectrum | Autism Research News}

https://www.spectrumnews.org

"It motivated me to be much more broadly informed about various human conditions," Cline says. "That was definitely very rewarding for me."

In 2008, Cline moved her lab to the Scripps Research Institute, where she continues to oversee research on inhibitory and excitatory neurons and conditions in which their balance is disrupted, as in autism and related conditions. And in 2014, she discovered that frogs that lack FMRP make fewer neurons than frogs that have working copies of the gene.

Since 2016, Cline has been director of the Dorris Neuroscience Center at the Scripps Research Institute, an airy, open lab environment that is home to 11 scientists. She sees mentoring younger women as crucial, she says. Her lab meetings regularly include discussions of how to improve representation in science, and she has received both the Scripps Research Institute Outstanding Mentor Award and the Society for Neuroscience's Mika Salpeter Lifetime Achievement Award specifically for promoting the advancement of women in science.

Her job, as she sees it, is to provide "the intellectual environment and scholarly environment for people to do the work that is most motivating for them," she says. "I really think people work best when they're driven by their own inspiration and their own curiosity, and so I try to foster that in my group."

Cline actively encourages event organizers, grant committees and others in positions of power to feature women in their programs, colleagues say.

Nedivi - who did postdoctoral research with Cline - says Cline taught her "everything." Cline and Nedivi worked together for only two years, more than two decades ago, yet Nedivi says she still considers Cline one of her closest friends. Others among Cline's colleagues and former students describe her as a respectful, supportive leader who doesn't see herself as being above others.

As her investigative scope and responsibilities have expanded, Cline says she has continued to consider herself a basic science researcher. Just as much as her work studying autism-related genes has elucidated some of the condition's underpinnings, it has also enabled her to gain a better understanding of the brain as a whole.

Studying Rett syndrome, for example, helped Cline answer a fundamental question about cell communication in the brain - a discovery that could, in turn, lead to a treatment for the genetic condition, which predominantly affects girls and often co-occurs with autism. She'd heard a talk by geneticist Huda Zoghbi, who discovered the gene that, when mutated, causes Rett syndrome. Cline was perplexed by how the girls lost previously acquired skills in early childhood. 


\section{Spectrum | Autism Research News}

https://www.spectrumnews.org

Admittedly based on little more than a hunch — what she describes as "like an idea you have in the shower" - Cline theorized that brain cells' typical process of exchanging information using exosomes, or packages of protein, DNA and RNA, goes awry in children with Rett, causing widespread regression in brain function.

To test the idea, she enlisted neuroscientist Alysson Muotri, who had built a human stem-cell model of Rett syndrome. Her hunch turned out to be right: In a dish, Rett syndrome neurons form few synapses on their own, but given exosomes from control neurons, they flourish.

"The strategy in science is: You observe something, you see something happen, and then you kind of push it to change it," Cline says. "Based on how it responded to your push, you learn something new."

Cite this article: https://doi.org/10.53053/WIDQ6077 